\title{
Meetings of Narrative and the Female Icon: Intervention in the Paintings of Joanne Tod
}

\author{
Karen Bernard
}

\section{Les rencontres du récit et de l'icône femme: l'intervention dans l'oeuvre peint de Joanne Tod}

Ce texte explore le travail d'une peintre Torontoise, Joanne Tod, sur la narration en peinture. Traditionellement opposé, l'image et le récit $s^{\prime}$ entremêlent dans la peinture. Dans l'oeuvre de Joanne Tod, le côté narratif de la peinture est dévéloppé et mobilisé contre l'ordre iconique pour interrompre les récits culturels qui fonctionnent, dans les mots de Teresa de Lauretis, comme une 'technologie de genre,' c'est à dire, des représentations qui construisent l'ordre sexuel avec ses divisions binaires et inégalitaires entres les sexes. Le travail de Tod fonction comme 'le polémique caché' identifié par Bakhtin comme une des modalités du discours double subversif du dialogisme. Tod emploie les techniques du réalisme mimétique en peinture précisérnent pour les critiquer. Dans 'Auto-portrait,' elle peint une image de femme plutôt stéréotypée, tirée des images des revues de mode des années vingt. Icion discerne une opposition entre ce que le titre 'dit' et ce que l'image 'dit,' stratégie caractéristique du travail de Tod surl'idéologie sexiste dominante et sa construction de 'l'identité' de la peintre. Plus tard, elle emploie cet auto-portrait dans un tableau 'Auto-portrait comme putain,' où elle continue sa méditation sur la réprésentation et l'autoreprésentation. Ici le tableau est placédans le décor d'une salleà manger bourgeoise ordinaire avec la porte ouverte pour signaler l'arrivé de la ménagère. Le récit du marriage pour l'amour éternel est ici mise en question. Le dernier tableau en question est 'La magie à Sao Paolo' où la peintre critique la canonisation des arts visuels au Canada. Elle peint elle-même et son amie Elizabeth MacKenzie au biennal de Sao Paolo comme si produit sur la revue $C$. Une revue d'art, ceci fut chargé de choisir les représentants du Canada à cet évenement intérnational. Tod critique à la fois le sexisme de cette périodique prétendue d'avant-garde et ses propres désirs de se faire honorer par une institution patriarcale. 


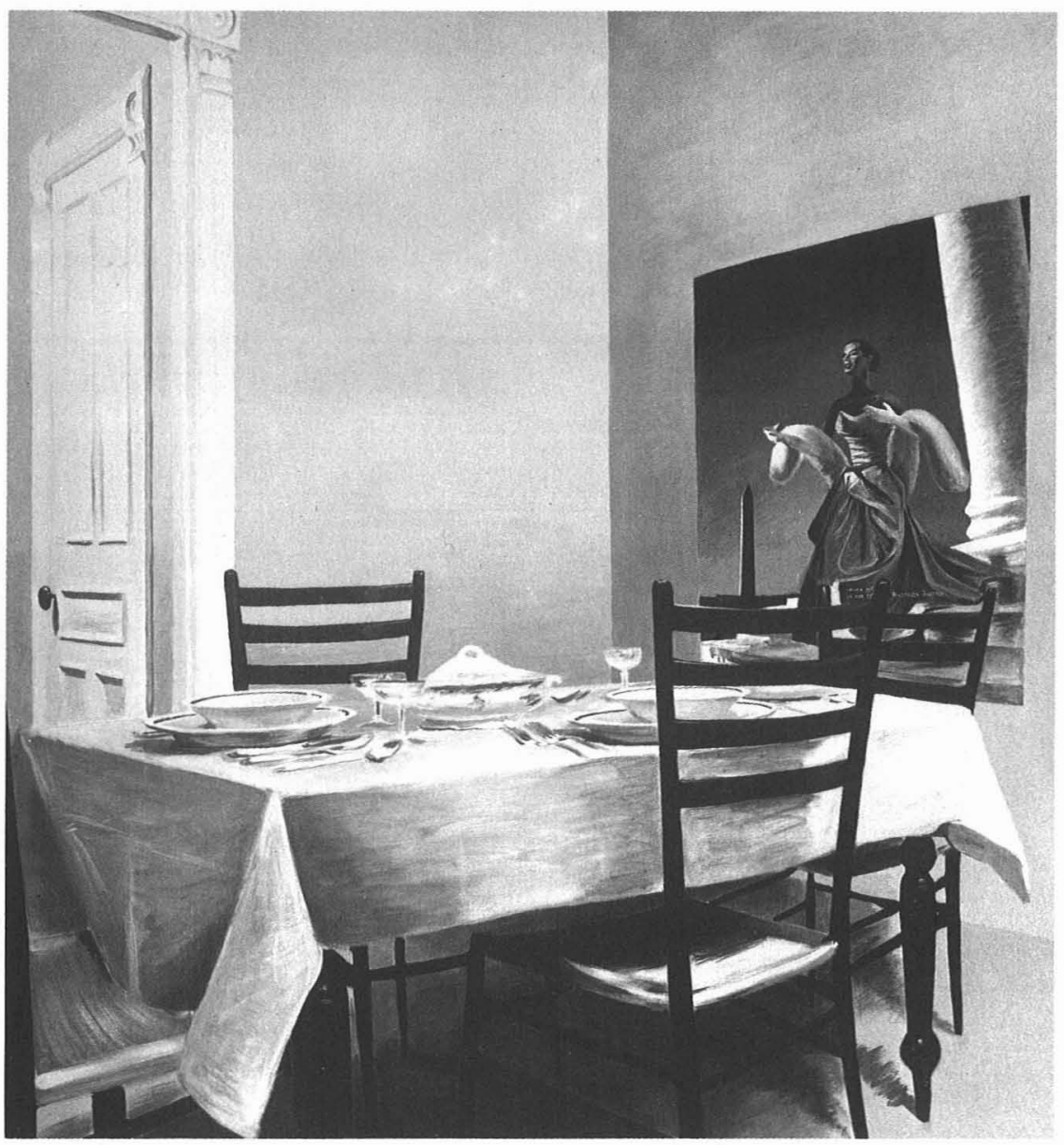

Joanne Tod. Self portrait as prostitute 1983

Acrylic on canvas $149.8 \times 139.8 \mathrm{~cm}$

Courtesy Carmen Lamanna Gallery, Toronto. 
Par ce travail de déstabilization et de fragmentation de grands récits culturels, Tod fait une intervention féministe dans les arts plastiques.

The surface of a painting may not seem, initially, the proper place of narrative activity. However, narrative is a ubiquitous cultural form, crucial to the representation of gender, and potentially occupies all the topoi of our culture. The most provocative contemporary visual art, such as that of Barbara Kruger, Martha Rosler and others, explicitly foregrounds the imbrication of the verbal and the iconic, suggesting their mutual complicity in the reproduction of our society's asymmetries of power. In a recent article, Robert Morris notes that despite the drive of Western rationality to clearly define and segregate the realms of word and image, the two representational systems remain entangled.

Perhaps nowhere is the entanglement and contamination between image and language more demonstrable than at the site of the aesthetic, for here the response of judgement does something more than dwell on the continuousness of the artifact. It breaks that surface and reads it as a series of discontinuous signs. 1

Even a visual art would deny any collaboration with the order of words is threatened by the act of its reception, which is always a 'reading' in the general sense. The seriality, or diachronic procedures, of language constitutes its essential narrative capacity, which one can argue is enacted synecdochally at the level of the sentence.

In the paintings of Joanne Tod, the narrative possibilities of visual art are not suppressed, but rather mobilized and played against the iconic order for the purpose of interrupting cultural processes which operate in the field of gender. One critic has hinted at Tod's embracing of narrativity by characterizing her overarching project as 'the strategy of the event; ${ }^{2}$ it is exactly her paintings' intersection with sociocultural events - such as politically contentious incidents or the quotidian events of women's constitution as gendered subjects which forge her alliance of the pictorial with the narrative. Behind or across each of her paintings runs a story that can be inferred. The paintings present a synchronic moment excerpted from this narrative, in which a feminist critique is proffered. 
In the three paintings I will discuss, the recurring referent is, in a general sense, the female person. The conflict of opposing intentions towards, and understandings of, this referent as dramatized in Tod's work can be explicated in terms of what Bakhtin calls 'hidden polemic.'

In hidden polemic the author's discourse is oriented toward its referential object, as is any discourse, but at the same time each assertion about that object is constructed in such a way that, besides its referential meaning, the author's discourse brings a polemical attack to bear against another speech act, another assertion on the same topic. Here one utterance focussed on its referential object clashes with another utterance on the grounds of the referent itself. ${ }^{3}$

These paintings, I will argue, advance a polemic against culturally dominant and naturalized representations of women. The irreducible multiplicity of Tod's work takes the form of inhabiting these dominant representations and at the same time undermining them.

The characteristics of Tod's painting technique are derived, initially, from her loyalty to a high realist tradition. One critic describes this traditional quality of Tod's style, and some ensuing implications for the viewer:

These surfaces are rich, elegant, painterly in the tradition of the Enlightenment painters, epitomized byJean-HonoréFragonard. In keeping with the objectivity of rationalism, viewers expect a representation of the truth. But Tod's visual discourse is ambiguous. One representation breaks through another, destroying the unity of the image and its power. ${ }^{4}$

The conventional or inherited aspect of Tod's visual vocabulary is the realm of the 'spoken subject' 5 - the established, culturally coded representations of women which appear natural. In the trajectory or metanarrative of realism throughout art history, women are continually and already inscribed on the canvas' surface in particular shapes and arrangements. The most familiar of these is the reclining odalisque, and the most omnipresent characteristic of gendered representations is the frozen positioning of women as magnet of the male 
gaze. The colours of Tod's palette, the eminently recognizable forms which represent people and objects in her work, and the relatively refined brush stroke derive from a long-standing mimetic impulse in figurative painting. However, Tod appropriates the conventions of pictorial realism only in order to counteract them, chiefly by means of incongruous assemblages of elements within the painting.

The first picture to which I will turn is her well-known 'Self-Portrait,' which was proclaimed as an emblem of the New Figurative or Neo-Expressionist art when first displayed at the watershed Monumenta exhibition at YYZ gallery in September 1982. The immediate irony of this piece is that its title does not accurately describe it; that is, the artist herself does not resemble the image in the 'self-portrait.' Perhaps one need not beacquainted with the artist's looks to ascertain this discrepancy, for the female image in the painting clearly shows the marks of being from a definite elsewhere. The image is, in fact, copied from a photo which Tod found in a 1920's Harper's Bazaar magazine, and bears the unmistakable features of an icon transported from the netherworld of fashion photography. The woman is arranged against a decorative, urbane, and loudly American landscape (on the steps of the Lincoln Memorial, with the Washington monument behind her). She is motionless, like a cadaver or plastic mannequin - the requisite pose for optimal display of clothing to the consumer. She embodies the relative bodily proportions demanded of fashion models, and wears the benignly discreet facial expression of woman as spectacle.

The disruptiveness of this work is generated, at one level, by the tension between what the title 'says' and what the image 'says' - two disparate assertions. At this point, I wish to borrow from a feminist development of cultural discourse theory, in Teresa De Lauretis' work, to establish the larger significance of the narrative sequence in which women read fashion magazines and acquire habits or styles of dress. De Lauretis tracks the process of the cultural construction of the gendered subject, in which male and female aresolicited differently by social institutions:

the discrepancy, the tension, and the constant slippage between Woman as representation, as the object and the very condition of representation, and, on the other hand, women as historical beings, subjects of 'real relations,' are motivated and sustained by a logical contradiction in our culture and an irreconcilable 
one: women are both inside and outside gender, at once within and without representation. That women continue to become Woman, continue to be caught in gender as Althusser's subject in ideology, and that we persist in that imaginary relation even as we know, as feminists, that we are not that, but we are historical subjects governed by real social relations, which centrally include gender - such is the contradiction that feminist theory must be built on, and its very condition of possibility. ${ }^{6}$

This process of the cultural construction of women is pictured in Tod's 'Self Portrait,' and at the same moment challenged. If gender is ideological in Althusser's sense, as De Lauretis claims, then it must function unnoticed to be most effective. While a reader of a fashion magazine may unconsciously recognize herself, or her desired self, in its photographs, Tod's displacement and estrangement of the same image disrupts this seamless flow of the daily and shifting constitution of women's identities, in which a sense of the self is elaborated. Tod's choice of title emphasizes that it is her self at stake in the seemingly anonymous and artificial image of a fashion-clad female.

The image is displaced from the glossy pages of its original milieu onto the less likely scene of the canvas of contemporary postmodern painting, where it is no longer subjugated to an apparent socio-economic function - that of commodity circulation. Another element adding to the estrangement of the image is the legend which runs across the center of the canvas. A convention of fashion magazines, as Barthes noted in Système de la Mode, is to accompany the photo with a line of text which describes the article purveyed in the image. ${ }^{7}$ Ostensibly, this is why the model's gown in the painting is traversed by a line of text, however, the content of this text is startlingly inappropriate for the genre of fashion commentary. It reads, "neath my arm is the color of Russell's Subaru,' an oddly personal remark, which highlights the artist's personal investment in this image and opens onto a narrative which is inaccessibly idiosyncratic. Again, this comment underscores the nature of the piece as a self-portrait, since the possessive pronoun 'my' should refer to Benveniste's 'speaking subject' - the initiator of the speech, in this case undecidable as either the model figure or the artist. The irony of this heavily personal fragment of text juxtaposed with the public image of a fashion model intimates the complicity of the female artist and all women in technologies of gender. 
In a later use of this painting, Tod incorporates 'Self Portrait' into a larger canvas called 'Self Portrait as Prostitute.' The gesture of engulfing the first painting within the second shows that Tod continues to be concerned with the problematic of self-representation, so that the first self-portrait requires the later supplementation of a sequel. The title of the second one also points to an awareness of the inevitable role-playing involved in identity, by bringing in the 'as if' dimension of self-ness - what Gayatri Spivak has called negotiable ontological commitments. ${ }^{8}$ The encapsulation of the earlier painting within the later emphasizes that a work of art (in this case, the first 'Self Portrait') is never closed or finished, even when it has hung in a public exhibition. In this way, the processes of identity formation and of artistic production can be seen as analogous in their interminability.

In the second painting, the self-portrait hangs on the wall of an empty, ordinary dining room. The table is set, and the door is invitingly open. Tod has remarked that this painting serves as a warning to herself of the possible commodification of her work, which may be consumed as quickly and thoughtlessly as will the pot of soup depicted on the table. The award-winning 'Self-Portrait' now decorates the wall of a private household, in a room whose open door implies an invitation tendered to a viewer / John from theartist / prostitute. Such a scene suggests the extent to which the artist hopes to entice male critical approval.

The open door is ambiguous enough, though, to allow for another line of interpretation; if it leads to the kitchen rather than some type of living room, then it points to the domestic labour requisite to the soup's eventual arrival at the table. This labour, unpaid and often unacknowledged, must remain discreetly hidden to ensure the charm and novelty of its final result, and so that the attendant social relations run smoothly and unquestioned. The painting on the wall is served up along with the meal, and the labour which produced the art object must also be concealed in order for its consumption to be facilitated. The only human figure in this second painting is off to the side, that is, in the reproduction of the first picture which overlooks the table. According to the conventions of realistic painting, the most important image in the painting, especially in the case of a portrait, should be centered. Perhaps the self-depiction here is not the image on the wall, but rather the implied image of the person whose absence in the painting is centrally notable; according to the predictive and proairetic codes of 
narrative realism, within which this painting can operate, the open door may also signal the imminent entrance of the housewife - the protagonist who would complete this scenario. Prostitution works then as a trope which critiques the exploitation of women in a bourgeois domestic arrangement. On this level, as well, the picture serves as a warning to the artist and other women, that to allow oneself to follow the most mainstream roles which our society offers women is equivalent to accepting the subjugation more dramatically played out in literal prostitution.

The last painting I will discuss is Tod's Magicat Sao Paolo.' Knowledge of the context is crucial in all of her work, and especially in this piece. The painting responds to an incident which occurred in the inner circles of the Canadian art world in 1985. That year, the male editor of a prominent Canadian art magazine, $C$, was responsible for selecting the Canadian participants in a Biennial Celebration in Sao Paulo, Brazil. Neither Tod nor her friend Elizabeth MacKenzie - both pictured recognizably in this image - were invited to attend. At the same time, factions within the Toronto arts community hotly contested the selection of participants in the biennial, and suspicions of nepotism were voiced.

Tod's reply to this controversy is to paint herself and friend into the very locale from which they were excluded, working from an actual photograph of a nightclub in Sao Paulo. Tod copied the photo faithfully, simply replacing the heads of strangers with hers and MacKenzie's. This forbidden location is at the same time the front cover of an issue of $C$, as indicated by the edge of its logo at the top of the canvas. The critical viewpoint of this piece emerges in its ability to signal presence and absence simultaneously. Tod's literal banishment from both of the places is contradicted by the solidity and apparent verisimilitude of this visual depiction of herself there. In the art world, as in other spheres of social life, women are 'the underdog,' in Tod's own words. Their exclusion from glorified events and stories is not accidental but systematic, and $C$ undermines its apparent progressiveness, as an institution linked to the parallel gallery network, by seeming to perpetuate sexual inequity.

At the same time, it seems that Tod is questioning herown desire for the prestige which patriarchy has to offer, by picturing herself and friend as somewhat ill at ease in theglamorous Braziliannight life. The two women appear less integrated into the crowd than the others 
present, and their bodies appear constrained within rigid garments of a type obligatory to the formal occasion - fancy gowns which sculpt the female body forcibly into uniform contours. Their gaze away from the rest of the crowd marks an oblivion to the festivities, and the very presence of the two female figures in this scenario (at the fringes of the crowd) has an air of improbability, almost to the extent of producing a surreal or magical quality.

The word 'magic' in the title imparts several connotations. It may sardonically imply the naturalizing of a male monopoly of society's power, the exercise of which can seem mysterious and of obscure origin. On another level, it may refer to Tod's capabilities as an artist, her ability to 'magically' represent herself in a scene from which she has been expressly excluded. Tod's inclusion of a CIBC logo within the frame of the painting, disguised as the steps into a swimming pool, also implicates corporate finance in the 'magical' exercise of heavily concentrated power.

The necessity to counteract exclusion is, of course, predicated on the marginality of women, that is, their placement on the outskirts of society's power circles. This is the predicament which Tod recognizes and in which her paintings intervene. The continued marginality of women is facilitated through representation, narrative and otherwise, and Tod's work acts on both of these fronts. Her paintings typically interrupt and unsettle a particular narrative which impinges on the lives of women. Thus feminist art often works as a destabilizing force from within the presently existing social order, in which it is necessary to wrest gendered representations from patriarchal control, and to fragment those reigning narratives which would make the subordination of women seem acceptable.

\section{Notes}

1. Robert Morris, 'Words and Images in Modernism and Postmodernism,' Critical Inquiry 15, 2 (Winter 1989): 340.

2. Bruce Grenville, 'Joanne Tod,' Catalogue (Southern Alberta Art Gallery, 1986).

3. Mikhail Bakhtin, Discourse Typology in Prose,' ed. Ladislav Mavejka and Kryshina Pomorska, Readings in Russian Poetics (London, 1971), p. 187.

4. Janice Andraea, 'Joanne Tod,' Parachute, Sept / Oct / Nov 1988, p. 62.

5. Kaja Silverman, The Subject of Semiotics (Oxford U. Press: Oxford, 1983). 


$$
\text { 64. Tessera }
$$

6. Teresa De Lauretis, Technologies of Gender (Bloomington: Indiana U. Press, 1987), p. 10.

7. Roland Barthes, Système de la Mode (Paris: Seuil, 1967).

8. This concept was theorized in her course, 'Deconstruction and the Margins of Theory,' at the International Summer Institute in Semiotics and Structural Studies 1988, held at the University of British Columbia. 